\title{
Prevalence of orofacial clefts and social factors in Brazil
}

Katamara Rodrigues ${ }^{(a)}$ Marina Fernandes de Sena ${ }^{(b)}$ Ângelo Giuseppe Roncalli(c) Maria Ângela Fernandes Ferreira ${ }^{(c)}$

(a) Specialist in Collective Health;

(b) Undergraduate Student, Department of Dentistry; (c) PhD, Professor, Department of Dentistry - Federal University of Rio Grande do Norte, Natal, RN, Brazil.
Corresponding author:

Marina Fernandes de Sena

Av. Praia de Ponta Negra, 8840,

Ponta Negra

Natal - RN - Brazil

CEP: 59094-100

E-mail: marinafsena@yahoo.com.br

\begin{abstract}
The aim of this study was to investigate the prevalence of orofacial clefts in live newborns from 1998 to 2002 in Brazilian state capitals and correlate their occurrence with a number of relevant socioeconomic factors collected in the 2000 census. Data was obtained from the Public Health Hospital Information System (SIH-SUS), Information System of Live Hospital Births (SINASC) and Atlases of Human Development in Brazil. The results showed that the mean prevalence of orofacial clefts in Brazil was 0.36 per 1,000 live births. Using Pearson's correlation coefficient, the correlation between cleft rate and social factors was not statistically significant $(\mathrm{p}>0.05)$. Our study suggests that there is no correlation between the municipal economic factors and the prevalence of orofacial clefts, which is likely influenced by underrecording problems in the less developed municipalities.
\end{abstract}

Descriptors: Cleft palate; Socioeconomic factors; Epidemiology. 


\section{Introduction}

Orofacial clefts are one of the most common congenital facial anomalies. They result from a failed fusion of the medial, lateral and maxillary processes, which should occur from the $6^{\text {th }}$ to the $10^{\text {th }}$ week of intrauterine life, approximately. ${ }^{1}$

The epidemiologic data of a longitudinal study in Bauru, SP, reveals a prevalence of 1.54 oral clefts per 1,000 live births. ${ }^{2}$ Another study conducted with newborns from two hospitals in Porto Alegre, RS, between 1970 and 1974, estimated an oral cleft prevalence of 0.88 per 1,000 live births. ${ }^{3}$ A study analyzing 12,782 maternity ward records found a prevalence of 0.42 per 1,000 live births. ${ }^{4}$ Loffredo et al. ${ }^{5}$ (2001) estimated a prevalence of 0.19 per 1000 live births over a 20 -year assessment period.

Few studies in Brazil have been conducted on the prevalence of oral clefts owing to difficulties involved in notification and recording. The more reliable records are made in the more developed urban centers, limited to specialized maternities and hospitals. Thus, these records do not represent the actual epidemiological situation of this condition in Brazil.

Latin American prevalence estimates, in the period from 1982 to 1990 , indicated a global rate of 1:953; Venezuela, Uruguay and Brazil presented the smallest rates. ${ }^{6}$ In European countries, the prevalence rate varies from 1.3 to 1.81 per 1,000 born. $^{7}$

In general, epidemiological information related to cleft lip and palate in children groups is not available due to reduced samples and the risks of irregularity in notification, when clefts are not registered immediately after birth. ${ }^{8}$

The etiologic factors are related to genetic interaction and environmental factors (infectious agents, ionizing radiation, licit or illicit drugs, hormones and nutritional deficiencies), ${ }^{9,10}$ which are responsible for 70 to $80 \%$ of all cases. ${ }^{11}$ The genetic component is considered the main causal factor in 25 to $30 \%$ of the observed cases. ${ }^{12}$

In addition to these factors, studies in the literature show that socioeconomic conditions are related to a variety of health consequences and represent contributing factors to congenital anomalies, such as orofacial clefts. ${ }^{13,14}$

Based on these considerations, the aim of this study was to determine the prevalence of orofacial clefts in newborns in Brazil from 1998 to 2002 and assess if the social differences could predispose the Brazilian population to orofacial clefts.

\section{Material and Methods}

An ecologic study was conducted using records of new orofacial cleft cases during the period from 1998 to 2002, in the regions and state capitals of Brazil, by consulting the Public Health Hospital Information System (SIH-SUS), which is administered by the Ministry of Health, and processed by Datasus $^{15}$ (Department of Information Technology of the National Health System), according to sex, geographic region and state capital. For the same period, the live births data and conditions were obtained from the Information System of Live Hospital Births (SINASC), ${ }^{15}$ which is administered by the Department for Analysis of the Health Situation of the Secretary of Health Vigilance.

In order to stabilize the prevalence data for the geographical regions and for the state capitals, the following relation was used for a five-year period (1998-2002):

$$
\mathrm{P}=\frac{\text { Total of cases }}{\text { Total of live borns }} \times 1,000
$$

Socioeconomic factors were obtained from the Atlases of Human Development in Brazil, an electronic database based on the microdata of the 1991 and 2000 censuses conducted by the Brazilian Institute of Geography and Statistics (IBGE). ${ }^{16}$ The factors selected were the following: Human Development Index - HDI (income, longevity and education), Infant Mortality, Per Capita Income and Gini Index. A mean of the social factors for each geographic region was obtained for the municipalities and the state capitals. After data collection, statistical analysis was performed using Pearson's Correlation Index to assess if the mean coefficient of clefts from 1998 to 2002 was correlated to social components according to the 2000 census.

\section{Results}

According to the data obtained from the SIHSUS and SINASC, 5,764 new cases of orofacial 
clefts and 15,786,107 live births were recorded in Brazil from 1998 to 2002.

Thus, the prevalence of orofacial clefts in Brazil was 0.36 per 1,000 live births in the five year period, and there was a proportion of this occurrence in 1.6 men for every female.

Analyzing the distribution of orofacial cleft cases by Brazilian geographical regions, a greater prevalence in the South $(0.43$ per 1,000$)$ and Midwest regions $(0.40$ per 1,000$)$ was observed. The lowest prevalence was observed in the North region $(0.26$ per 1,000) (Table 1). The Brazilian capitals that presented the highest and lowest prevalence were, respectively, Curitiba $(0.78$ per 1,000$)$, situated in the South region, and Palmas (0.16 per 1,000$)$, in the North region.

The majority of the geographical regions exhibited Human Development Index (HDI) values between 0.500 and 0.799 , classified as average. The

Table 1 - Prevalence of orofacial clefts according to sex and geographical regions in Brazil, per 1,000 live births (1998-2002).

\begin{tabular}{l|c|c|c}
\hline \multicolumn{1}{c|}{ Regions } & Man & Woman & Total \\
\hline Midwest & 0.24 & 0.16 & 0.40 \\
\hline Northeast & 0.23 & 0.16 & 0.39 \\
\hline North & 0.16 & 0.10 & 0.26 \\
\hline Southeast & 0.21 & 0.13 & 0.34 \\
\hline South & 0.27 & 0.16 & 0.43 \\
\hline BRAZIL & 0.22 & 0.14 & 0.36 \\
\hline
\end{tabular}

Source: SIH-SUS and SINASC/DATASUS. ${ }^{15}$

Table 2 - Social factors according to geographical regions, 2000.

\begin{tabular}{l|c|c|c|c}
\hline \multicolumn{1}{|c|}{ Regions } & $\begin{array}{c}\text { Infant } \\
\text { Mortality } \\
\text { Rate }\end{array}$ & $\begin{array}{c}\text { Gini } \\
\text { Index }\end{array}$ & $\begin{array}{c}\text { Human } \\
\text { Development } \\
\text { Index }\end{array}$ & $\begin{array}{c}\text { Per capita } \\
\text { Income* }\end{array}$ \\
\hline Midwest & 26.57 & 0.58 & 0.740 & 123.04 \\
\hline Northeast & 53.51 & 0.58 & 0.610 & 50.09 \\
\hline North & 40.88 & 0.61 & 0.664 & 70.86 \\
\hline Southeast & 24.4 & 0.54 & 0.745 & 130.72 \\
\hline South & 18.30 & 0.53 & 0.771 & 137.46 \\
\hline BRAZIL & 32.73 & 0.57 & 0.706 & 102.44 \\
\hline
\end{tabular}

Source: Atlases of Human Development in Brazil. ${ }^{16}$ *(in U.S. dollars).
Table 3 - Pearson's correlation coefficient ( $r$ ) between orofacial cleft prevalence and social factors. Brazil, 19982002.

\begin{tabular}{c|c|c}
\hline Factors & $r$ & $p$ \\
\hline Human Development Index & -0.072 & 0.723 \\
\hline Gini Index & 0.084 & 0.676 \\
\hline Per Capita Income & -0.054 & 0.790 \\
\hline Infant Mortality Rate & -0.094 & 0.642 \\
\hline
\end{tabular}

Source: Atlases of Human Development in Brazil. ${ }^{16}$

best municipal HDI was found in the South region (0.771), while the worst index was obtained in the Northeast and North regions, respectively 0.610 and 0.664 (Table 2). Analyzing the data for the capitals, the best municipal HDI was found in Florianópolis (0.875) and Porto Alegre (0.865), both located in the South region, while the worst index was obtained in Maceió (0.739) and Rio Branco (0.754), in the Northeast and North regions, respectively.

The Gini Index represents the degree of income concentration in a given city or region. The worst income distribution was observed in the North region (Gini Index 0.61) and the best distribution was observed in the South region (Gini Index 0.53) (Table 2).

The South presented the greatest monthly per capita income, in U.S. dollars, (\$137.46) and the Northeast, the smallest (\$50.09) (Table 2).

The infant mortality rate in Brazil was 32.73 deaths per 1,000 live births in 2000. The Northeast region had the highest infant mortality rate, which was more than twice as big as that of the South, Southeast and Midwest regions, reaching levels around 53.51 infant deaths per 1,000 live births (Table 2).

The results of the correlation between orofacial cleft prevalence and social factors did not reveal statistical significance $(\mathrm{p}>0.05)$, as shown in Table 3 .

\section{Discussion}

In this study, the social inequities in Brazil that could predispose the population to orofacial clefts were assessed, given that a number of studies demonstrate that the majority of cleft cases occur in children living under low socioeconomic conditions. ${ }^{16,17}$ 
By appraising these social factors in the geographical regions and Brazilian state capitals, our intention was to map the relationship between social inequity and the prevalence of orofacial clefts. Nonetheless, the results did not show any significant association, since the greatest disparity observed in social factors from the North and Northeast regions of the country was not directly proportional to the presence of orofacial clefts. Nevertheless, it must be pointed out that a positive correlation does not mean that socioeconomic status is an etiologic factor in the congenital anomalies under study, but only that it favors a greater exposure to the risk factors, as presented in other studies.

It is important to consider that, in those regions that displayed the lowest prevalence of orofacial clefts, the cases could be underestimated. Furthermore, the most important centers for orofacial clefts are located mainly in the Southeast region of the country.

Another relevant question is the misdiagnosis of orofacial clefts, mainly those associated to syndromes and cleft palate cases. Similarly, children that die during birth or even prior to delivery are often not recorded as having orofacial cleft.

Another important limitation of the present study is that the prevalence of clefts was correlated only to the socioeconomic status of the geographical region and state capital, and not to the individual socioeconomic status. It is conceivable that even in those areas with a general low socioeconomic status, the population who has easier access to health care services is that with a higher socioeconomic status. This factor might again mask possible differences between different regions/cities.

The underrecording reputing can be easily observed when comparing orofacial cleft prevalence data among different age groups. The age group used for this study represented only $7.5 \%$ of all the records, in the period assessed. There is also a large percentage of late-reported records up to 29 years of age, totaling around $87 \%$ of all the records. ${ }^{15}$ All of this implies underrecording, thus causing limitations when researching secondary data, and represents an important bias in our study.

In the literature there is considerable controversy over the probable correlation between social factors and orofacial clefts, due to the methodological diversity found in the different study designs. Some researchers found an association between children with orofacial clefts and socioeconomic conditions, ${ }^{13,14,17}$ whereas others did not. ${ }^{18,19}$

In a case-control study this relation was examined based on the 1990 census and assessed education, unemployment, occupation, income, housing and poverty. ${ }^{18}$ The study concluded that there was no association between social conditions and orofacial clefts. Similarly, a study with the same epidemiological design assessed the data of 858 cases and 1,764 controls in various European malformation centers, associating them with socioeconomic data of the census, and found no evidence that socioeconomic variations could interfere or increase oral cleft cases or neural tube defects. ${ }^{19}$

On the other hand, Womersley, Stone ${ }^{17}$ (1987) observed that teratogenic factors are more prevalent in areas of greater socioeconomic deprivation, where unhealthy environmental conditions increase susceptibility to a specific teratogen, possibly causing orofacial clefts. This was not observed in the present study due to the different methodological characteristics.

This idea is corroborated by an investigation developed in Rio de Janeiro, Brazil, showing that factors related to the environment and to the occupation of the parents were associated with the occurrence of orofacial clefts. ${ }^{20}$

Similar results were observed in a study of the distribution of cleft types in patients attended at a University Hospital in São Paulo. ${ }^{21}$ It was observed that $70 \%$ of the cases lived under unfavorable socioeconomic conditions.

The lack of correlation between the social factors of the 2000 census and the prevalence of orofacial clefts in the period from 1998 to 2002 is likely due to the limitations of this study and the databases that were used. In ecologic studies, it is not possible to associate exposure and disease at the individual level, given that the data collected represent mean exposure levels rather than true individual values. ${ }^{22}$ Furthermore, the data came from different sources, a fact that could mean a lack of reliability and consequently may impede the recognition of potential confounding factors. 
In this sense, regardless of how valid populationbased studies using information from databases may be, a more complete and detailed survey in hospitals, maternities and major centers for patients with orofacial clefts has greater discriminatory power to investigate the risk factors for orofacial clefts, particularly when one intends to make inferences to larger populations.

These studies are extremely important in that the polygenic and multifactor etiology of the anomaly could be better specified, and consequently the population may be better oriented to prevent its occurrence. Furthermore, support could be provided

\section{References}

1. Carreirão S, Lessa S, Zanini AS. Embriologia da face. In: Tratamento das fissuras labiopalatinas. $2^{\mathrm{a}}$ ed. Rio de Janeiro: Revinter; 1996. p. 1-12.

2. Nagem Filho H, Moraes N, Rocha RGF. Contribuição para o estudo da prevalência das más formações congênitas lábiopalatais na população escolar de Bauru. Rev Fac Odont USP. 1968;6(2):111-28.

3. Cândido TT. Epidemiologia das fendas de lábio e/ou palato: estudo de recém-nascidos em dois hospitais de Porto Alegre, no período de 1970 a 1974 [Dissertação de Mestrado]. Porto Alegre: Universidade Federal do Rio Grande do Sul; 1978.

4. Souza JMP, Buchalla CM, Laurenti R. Estudo da morbidade e da mortalidade perinatal em maternidades. III-Anomalias congênitas em nascidos vivos. Rev Saúde Pública. 1987;21(1):5-12.

5. Loffredo LCM, Freitas JAS, Grigolli AAG. Prevalence of oral clefts from 1975 to 1994, Brazil. Rev Saúde Pública. 2001 Dec;35(6):571-5.

6. Rodrigues MTC, Torres MEM. Labio y paladar fisurados. Aspectos generales que deben conocer en la atención primaria de salud. Rev Cubana Med Gen Integr. 2001;17(4):379-85.

7. Derijcke A, Eerens A, Carels C. The incidence of oral clefts: a review. Br J Oral Maxillofac Surg. 1996 Dec;34(6):488-94.

8. Mitchell LE, Beaty TH, Lidral AC, Munger RG, Murray JC, Saal HM, et al. Guidelines for the design and analysis of studies on nonsyndromic cleft lip and cleft palate in humans: summary report from a workshop of the International Consortium for Oral Clefts Genetics. Cleft Palate Craniofac J. 2002 Jan;39(1):93-100.

9. Moore KL, Persuad TUN. Embriologia Clínica. $7^{\text {a }}$ ed. Rio de Janeiro: Guanabara Koogan; 2004.

10. Ten Cate AR. Embriologia do crânio, face e cavidade bucal. In: Ten Cate AR. Histologia Bucal - Desenvolvimento, Estrutura e Função. 2a ed. Rio de Janeiro: Guanabara Koogan; 1988. p. 11-34. for planning preventive interventions on the part of health programs promoted by the federal government.

\section{Conclusion}

Our study suggests that the municipal economic factors obtained through the 2000 census investigation were not correlated with the prevalence of orofacial clefts in the Brazilian population from 1998 to 2002 . These results may have been influenced by the problem of underrecording in the less developed municipalities and by the limitations of the study design itself.

11. Israel J. Genetic aspects of cleft palate and cleft lip and palate. In: Pirrucello FW. Cleft lip and palate. Springfield: Charles C.Thomas; 1987. p. 17-40.

12. Tolarová MM, Cervenka J. Classification and birth prevalence of orofacial clefts. Am J Med Genet. 1998 Jan;75(2):126-37.

13. Donkor P, Plange-Rhule G, Amponsah EK. A prospective survey of patients with cleft lip and palate in Kumasi. West Afr J Med. 2007 Jan-Mar;26(1):14-6.

14. Poletta FA, Castilla EE, Orioli IM, Lopez-Camelo JS. Regional analysis on the occurrence of oral clefts in South America. Am J Med Genet A. 2007 Dec;143(24):3216-27.

15. Ministério da Saúde (BR). DATASUS [on line] 2004. Disponível em URL: http://tabnet.datasus.gov.br/cgi/tabcgi.exe?sinasc/cnv/ nvuf.def.

16. Programa das Nações Unidas para o Desenvolvimento. Atlas do Desenvolvimento Humano no Brasil - versão 1.0.0. 2003. http://www.pnud.org.br/atlas/.

17. Womersley J, Stone DH. Epidemiology of facial clefts. Arch Dis Child. 1987 Jul;62(7):717-20.

18. Carmichael SL, Nelson V, Shaw GM, Wasserman CR, Croen LA. Socio-economic status and risk of conotruncal heart defects and orofacial clefts. Paediatr Perinat Epidemiol. $2003 \mathrm{Jul} ; 17(3): 264-71$.

19. Vrijheid M, Dolk H, Stone D, Abramsky L, Alberman E, Scott JE. Socioeconomic inequalities in risk of congenital anomaly. Arch Dis Child. 2000 May;82(5):349-52.

20. Leite ICG, Paumgartten FJR, Koifman SL. Orofacial clefts in the newborn and environmental and occupational parental exposures: a case-control study in Rio de Janeiro, Brazil. Rev Bras Saúde Mater Infant. 2003;3(4):401-9.

21. Freitas JA, Dalben G da S, Santamaria M, Freitas PZ. Current data on the characterization of oral clefts in Brazil. Braz Oral Res. 2004 Apr-Jun;18(2):128-33.

22. Medronho RA. Epidemiologia. $2^{\text {a }}$ ed. São Paulo: Atheneu; 2004. 